\title{
An Epitope Platform for Safe and Effective HTLV-1-Immunization: Potential Applications for mRNA and Peptide-Based Vaccines
}

\author{
Guglielmo Lucchese ${ }^{1, *,+}$, Hamid Reza Jahantigh ${ }^{2,3,+} \mathbb{D}$, Leonarda De Benedictis ${ }^{2}$, Piero Lovreglio ${ }^{2} \mathbb{D}$ and \\ Angela Stufano 2,3 (D) \\ 1 Department of Neurology, Medical University of Greifswald, 17475 Greifswald, Germany \\ 2 Interdisciplinary Department of Medicine-Section of Occupational Medicine, University of Bari, \\ 70124 Bari, Italy; hamidreza.jahantigh@uniba.it (H.R.J.); leonarda.debenedictis@uniba.it (L.D.B.); \\ piero.lovreglio@uniba.it (P.L.); angela.stufano@uniba.it (A.S.) \\ 3 Animal Health and Zoonosis Doctoral Program, Department of Veterinary Medicine, University of Bari, \\ 70010 Bari, Italy \\ * Correspondence: guglielmo.lucchese@uni-greifswald.de \\ + These authors contributed equally to the work.
}

check for

updates

Citation: Lucchese, G.; Jahantigh, H.R.; De Benedictis, L.; Lovreglio, P.; Stufano, A. An Epitope Platform for Safe and Effective

HTLV-1-Immunization: Potential Applications for mRNA and Peptide-Based Vaccines. Viruses 2021, 13, 1461. https://doi.org/10.3390/ v13081461

Academic Editor: Louis M. Mansky

Received: 20 June 2021

Accepted: 21 July 2021

Published: 27 July 2021

Publisher's Note: MDPI stays neutral with regard to jurisdictional claims in published maps and institutional affiliations.

Copyright: (c) 2021 by the authors. Licensee MDPI, Basel, Switzerland. This article is an open access article distributed under the terms and conditions of the Creative Commons Attribution (CC BY) license (https:// creativecommons.org/licenses/by/ $4.0 /)$.

\begin{abstract}
Human T-cell lymphotropic virus type 1 (HTLV-1) infection affects millions of individuals worldwide and can lead to severe leukemia, myelopathy/tropical spastic paraparesis, and numerous other disorders. Pursuing a safe and effective immunotherapeutic approach, we compared the viral polyprotein and the human proteome with a sliding window approach in order to identify oligopeptide sequences unique to the virus. The immunological relevance of the viral unique oligopeptides was assessed by searching them in the immune epitope database (IEDB). We found that HTLV-1 has 15 peptide stretches each consisting of uniquely viral non-human pentapeptides which are ideal candidate for a safe and effective anti-HTLV-1 vaccine. Indeed, experimentally validated HTLV-1 epitopes, as retrieved from the IEDB, contain peptide sequences also present in a vast number of human proteins, thus potentially instituting the basis for cross-reactions. We found a potential for cross-reactivity between the virus and the human proteome and described an epitope platform to be used in order to avoid it, thus obtaining effective, specific, and safe immunization. Potential advantages for mRNA and peptide-based vaccine formulations are discussed.
\end{abstract}

Keywords: HTLV-1; vaccine; peptide; adjuvant; similarity; autoimmunity

\section{Introduction}

Human T-cell leukemia virus-1 (HTLV-1) infection is associated with a broad spectrum of clinical manifestations such as bronchiectasis, bronchitis and bronchiolitis, dermatophytosis, community acquired pneumonia, strongyloides hyperinfection syndrome, liver, lymphoma and cervical cancer and several autoimmune/inflammatory disorders such as Sjögren's Syndrome (SS), arthropathies, and uveitis [1]. Among the many disorders that HTLV-1 carriers may develop, two are paramount: adult T-cell leukemia/lymphoma (ATL), an aggressive and often fatal hematological malignancy that is poorly responsive to most anticancer treatments, and a chronic neurological disease, HTLV-1-associated myelopathy/tropical spastic paraparesis (HAM/TSP) [1,2]. HAM/TSP patients present a series of immunological dysfunctions and among the several existing theories related to HAM/TSP development, one of the most widely accepted suggests that an autoimmune mechanism can cause lesions by molecular mimicry. A host neuronal protein seems to be similar to Tax protein from the virus, which can cause immune cross-reaction, leading to spinal cord inflammation [3].

While in certain endemic regions the prevalence and incidence of clinical symptoms among persons infected with HTLV-1 is significantly elevated, HTLV-1 infection 
leads to changes in the systemic immune response even in asymptomatic patients [4]. The HTLV-1 virus infects dendritic cells, monocytes and CD4+ helper T-cells and can induce changes in the activity of regulatory CD4 T-cell molecules, affecting the homeostasis of cytokines and disrupting the balance in inflammatory and anti-inflammatory responses, leading to the loss of tolerance and the development of autoimmunity. Moreover, previous research suggested that molecular mimicry could be a possible trigger mechanism for the development of autoimmune diseases linked to HTLV-1 infection [5].

To evoke proper immune responses against HTLV-1, especially cellular immunity without undesired side effects, development of an effective and safe vaccine is essential. Synthetic peptide-based vaccines have been developed to evoke immune responses with various advantages in comparison to conventional vaccine formulations. Peptide vaccines are intended to induce cellular and humoral immunity and are chemically stable without oncogenic potential [6].

Several peptide vaccines against HTLV-1 have been proposed [7] and seem to elicit a high cellular response and a significant decrease in the proviral load as well as partial protection in immunized animals, and moreover a recently developed anti-ATL therapeutic vaccine exhibited favorable clinical outcomes [8]. However, there are still no data regarding the potential use of these vaccines in view of prophylactic administration in the general population potentially exposed to this viral disease.

With the aim of investigating possible immunotherapeutic approaches against HTLV-1, we analyzed the HTLV-1 proteome in an attempt to extract peptide sequences belonging uniquely to the virus and absent in the human proteome. The research rationale was that immunotherapeutic approaches based on peptide sequences unique to the virus might be highly immunogenic by being unknown to the immune system, thus representing the "non-self" [9]. In addition, the anti-viral immunoreactivity would also have the advantage of being exempt from cross-reactions and consequent autoimmune pathologies [10]. According to this rationale, we define here a set of HTLV-1 peptides that might represent a platform for developing safe and effective anti-HTLV-1 vaccines.

\section{Methods}

The analyzed HTLV-1 polyprotein sequence (accession NCBITaxId11926) is described at https: / / www.uniprot.org/proteomes / ?query=11926\&sort=score, accessed on 1 September 2020 [11]. The HTLV-1 polyprotein sequence was cut into pentapeptides overlapping each other by four residues, i.e., MGQIF, GQIFS, QIFSR, and IFSRS. Then each HTLV-1 pentapeptide was analyzed for exact matches in the human proteome. Matching analyses of the viral polyprotein sequence to the human proteome were conducted using the Peptide Match Program (https:/ / research.bioinformatics.udel.edu/peptidematch/, accessed on 1 September 2020) [12]. The Immune Epitope Database and Analysis Resources (IEDB; http:/ / www.iedb.org/, accessed on 1 September 2020) was searched for peptide sequences unique to the virus in order to assess their immunological relevance [13].

\section{Results}

3.1. From Sequence Similarity Analyses to Anti-HTLV-1 Vaccination: Formulating a Specific and Effective Vaccine

Figure 1 reports the similarity profile of HTLV-1 amino acid (aa) sequence to the human proteome at the $5 \mathrm{mer}$ level. It can be seen that the occurrences of the viral pentapeptides show a constant pattern in the human proteome, with high redundant peptide areas that regularly alternate to viral peptide areas that are rare or absent in the human proteome. 


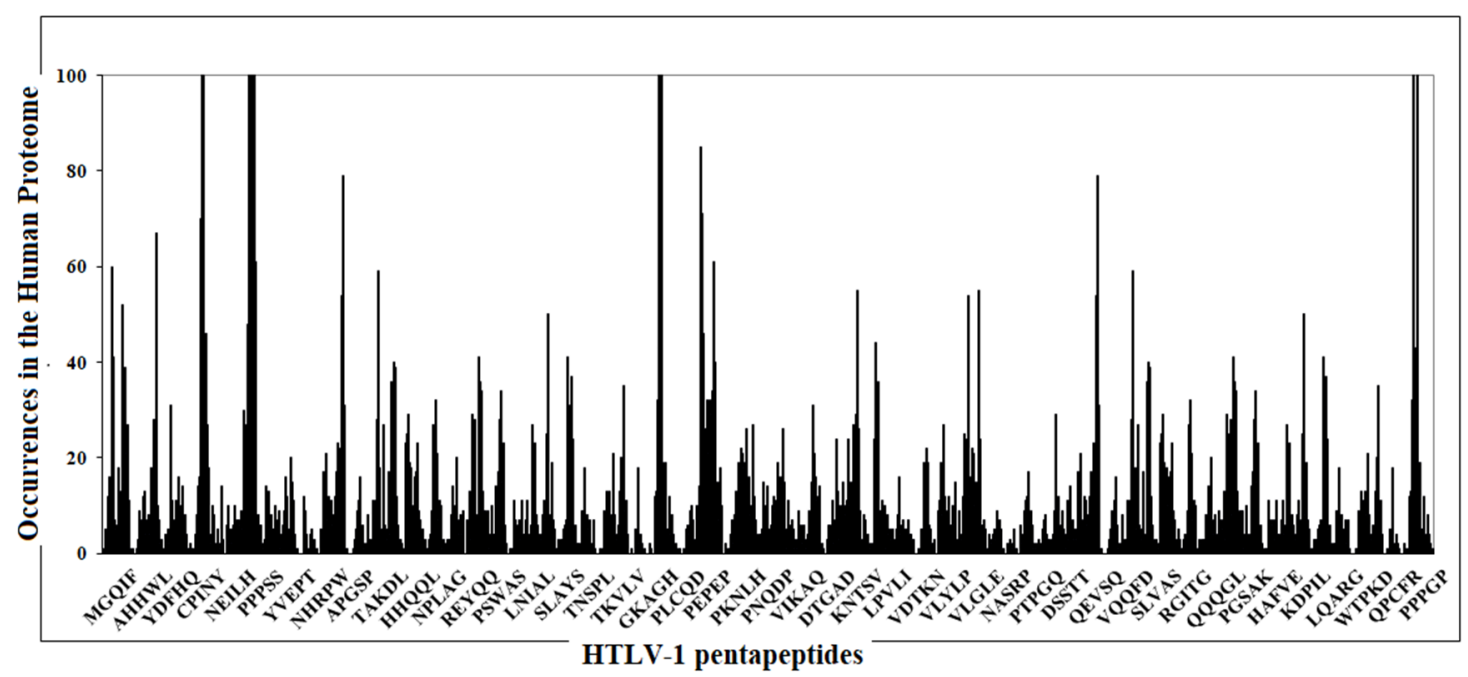

Figure 1. Matching profile of the HTLV-1 aa sequence to the human proteome at the pentapeptide level.

As a second step in our investigation, we searched among pentapeptides absent in the human sequences and eventually selected unique consecutive viral pentapeptides overlapping each other by four residues. The results are reported in Table 1, showing that HTLV-1 has 15 peptide stretches consisting of at least 3 pentapeptides overlapping each other by 4 residues, distributed among the viral proteins Gag polyprotein, Gag-Pro-Pol polyprotein, Envelope glycoprotein gp62, and Protein Tax-1.

Table 1. Peptides that are $\geq 7 \mathrm{mer}$ long and consist of overlapping minimal 5-mer immune determinants unique to HTLV-1 and absent in the human proteome.

\begin{tabular}{|c|c|c|c|}
\hline HTLV-1 Protein & AaPosition & Peptide $^{1}$ & MHC Binding ${ }^{2}$ \\
\hline Gag polyprotein & $132-138$ & VMHPHGA & HLA-B*07:02 \\
\hline Gag polyprotein & $165-171$ & PQFMQTI & $H L A-B^{*} 07: 02$ \\
\hline Gag polyprotein & $331-337$ & ACQTWTP & n.a. \\
\hline Gag polyprotein & $364-370$ & GHWSRDC & n.a. \\
\hline Gag-Pro-Pol polyprotein & $915-921$ & SKEQWPL & n.a. \\
\hline Gag-Pro-Pol polyprotein & $1086-1092$ & RSWRCLN & n.a. \\
\hline Gag-Pro-Pol polyprotein & $1351-1358$ & IALWTINH & n.a. \\
\hline Gag-Pro-Pol polyprotein & $1366-1374$ & HKTRWQLHH & n.a. \\
\hline Gag-Pro-Pol polyprotein & 1390-1398 & KQTHWYYFK & $\begin{array}{l}H L A-A^{*} 03: 01 \\
H L A-B^{*} 27: 05\end{array}$ \\
\hline Gag-Pro-Pol polyprotein & 1429-1435 & SAQWIPW & $\begin{array}{l}\text { HLA-A*24:02 } \\
\text { HLA-A*02:01 } \\
\text { HLA-B*35:01 } \\
H L A-B^{*} 58: 01\end{array}$ \\
\hline Protein Tax-1 & $49-56$ & CPEHQITW & n.a. \\
\hline Envelope glycoprotein gp62 & $116-122$ & GCQSWTC & n.a. \\
\hline Envelope glycoprotein gp62 & $131-137$ & PYWKFQH & n.a. \\
\hline Envelope glycoprotein gp62 & $170-176$ & YDPIWFL & n.a. \\
\hline Envelope glycoprotein gp62 & $272-278$ & NWTHCFD & n.a. \\
\hline
\end{tabular}

${ }^{1}$ Identified as described under Methods and in text. ${ }^{2}$ Detailed methods and discussion and in text. n.a. $=$ data not available. Bold indicates experimentally validated biding to the allele as reported in the IEDB; italics indicates predicted binding to the HLA-allele. 
Finally, the peptides described in Table 1 were analyzed for their immunologic potential as follows. HTLV-1 derived epitopes were retrieved from IEDB, and the epitopes that had been experimentally validated as immunopositive in HLA-binding, B cell, and T cell assays were analyzed for the presence of the peptide sequences unique to HTLV- 1 that are presented in Table 1. Moreover, predicted binding to HLA I molecules was further investigated with NetMHC 4.0. [14]. Heptapeptides were extended by 1 aminoacid (aa) residue, as naturally occurring in the viral proteome, in the $\mathrm{N}$-terminus for binding prediction. Experimentally validated and predicted binding to HLA class I molecules information is presented in Table 1.

Data from B cell and $\mathrm{T}$ cell assays as retrieved from the IEDB are reported in Table 2. It was found that the majority of the unique HTLV-1 peptides are present in immunoreactive epitopes with the majority of them allocated in HTLV-1 envelope glycoprotein, in accordance with the predominant role of the immune response against HTLV-1 envelope glycoprotein [15].

Table 2. Distribution among experimentally validated epitopes that are immunoreactive in the human host of peptides that are $\geq 7$ mer long, consist of overlapping minimal 5-mer immune determinants unique to HTLV-1, and are absent in the human proteome. ${ }^{1}$ (www.iedb.org, accessed on 1 September 2020). ${ }^{2}$ HTLV-1 peptides unique to HTLV-1 and absent in the human proteome are given in capital letters.

\begin{tabular}{cccc}
\hline IEDB ID & EPITOPE SEQUENCE ${ }^{2}$ & VIRAL PROTEIN & ASSAY \\
\hline 7612 & dapgYDPIWFLntepsqlpptappllphsnldhile & Envelope glycoprotein & B cell \\
17248 & fNWTHCFDpqiqaivsspchnslilppfslspvpt & Envelope glycoprotein & B cell \\
18895 & GCQSWTCpytgavssPYWFQHdvn & Envelope glycoprotein & B cell \\
20199 & GHWSRDCtqprpppgpcplcqdp & Pr gag-pro-pol.1 & B cell \\
34858 & lalpaphltlpfNWTHCFDpqiq & Envelope glycoprotein & B cell \\
38482 & lpfNWTHCFDpq & Envelope glycoprotein & B cell \\
47047 & pcslkcpylGCQSWTCpytgavs & Envelope glycoprotein & B cell \\
49915 & pVMHPHGAppnhrpwqmkdlqaikqevsqa & Pr gag-pro-pol.1 & B cell \\
59328 & sllvdapgYDPIWFLntepsqlpptappllphsnldhilepsipwks & Envelope glycoprotein & B cell \\
61300 & ssPYWKFQHdvnftqevsrln & Envelope glycoprotein & B cell \\
62700 & sysdpcslkcpylGCQSWTCpyt & Envelope glycoprotein & B cell \\
65003 & tlpNWTHCFDpqiqaivs & Envelope glycoprotein & B cell \\
65645 & tpllypslalpaphltlpfNWTHCFDpqiq & Envelope glycoprotein & B cell \\
78192 & lalpaphltlpfNWTHCFDpqiqaivsspchnsli & Envelope glycoprotein & B cell \\
78715 & latCPEHQITWdpidgrvig & Transcriptional activator Tax & B cell \\
94435 & apgYPIWFL & Envelope glycoprotein & T cell \\
96592 & lpfNWTHCFDpqiqaivsspc & Envelope glycoprotein & T cell \\
97892 & apqvlpVMHPHGAppn & Pr gag & B cell \\
\hline
\end{tabular}

3.2. From Sequence Similarity Analyses to Autoantibodies Generation: Potential Contribution to the HTLV-1 Pathological Burden

The data reported above not only open new scenarios for effective and specific antiHTLV-1 vaccine formulations, but can also provide a potential mechanistic link between HTLV-1 infection and related disorders including lymphomas and leukemias, respiratory disorders, fibromyalgia, rheumatoid arthritis, arthritis, tuberculosis, kidney and bladder infections, dermatophytosis, community acquired pneumonia, strongyloides hyperinfection syndrome, liver cancer, lymphoma, cervical cancer, and neurological disorders [1,2].

Indeed, analyses of the experimentally validated epitopes described in Table 2 for peptide sharing with human proteins reveals that, coherently with Figure 1, the HTLV-1derived epitopes are mostly composed of peptide sequences present in human proteins that, when altered, mutated, deficient or not functioning, may associate with numerous diseases related to HTLV-1 infection, thus supporting the possibility that cross-reactivity between the virus and human proteins can induce pathogenic autoantibodies and the HTLV-1 diseasome. 
Generation of autoantibodies following peptide sharing-induced cross-reaction would also explain the multitude of disorders that, to a greater or lesser extent, characterize HTLV-1 infection. Indeed, analyses of the peptide overlap between the viral epitopes and the human proteome show that, on the whole, 64 epitope-derived hexapeptides repeatedly occur among 143 human proteins (Table 3), thus providing an ample platform for crossreactions and, consequently, outlining a wide post-infection severe pathologic sequela.

Table 3. Peptide sharing between HTLV-1-derived epitopes and human proteins.

\begin{tabular}{|c|c|}
\hline Peptides & Human Proteins \\
\hline SLILPP & $\begin{array}{c}\text { (Pyruvate dehydrogenase (acetyl-transferring)) kinase isozyme 2, mitochondrial, Cilia- and flagella-associated } \\
\text { protein } 44 \text {, F-BAR domain only protein } 1 \text {, Suppressor of tumorigenicity } 7 \text { protein, Suppressor of tumorigenicity } \\
7 \text { protein-like }\end{array}$ \\
\hline PSLALP & 3-oxo-5-alpha-steroid 4-dehydrogenase 1, A-kinase anchor protein 1 mitochondrial precursor \\
\hline QPRPPP & $\begin{array}{l}\text { Acrosin precursor, Adipocyte enhancer-binding protein } 1 \text { precursor, Alpha-ketoglutarate-dependent } \\
\text { dioxygenase alkB homolog 6, Copine-9, Spectrin beta chain non-erythrocytic 2, Mitochondrial dynamics } \\
\text { protein MID49, Synapsin-3, TANK-binding kinase 1-binding protein 1, Tensin-1 }\end{array}$ \\
\hline PCSLKC & ADAMTS-like protein 1 precursor \\
\hline HLTLPF & A-kinase anchor protein 7 isoform gamma \\
\hline LALPAP & $\begin{array}{l}\text { Alpha-mannosidase 2C1, Membrane-associated phosphatidylinositol transfer protein 2, Palmitoyltransferase } \\
\text { ZDHHC1, Phosphatidylinositol 3-kinase regulatory subunit beta, Probable threonine protease PRSS50 } \\
\text { precursor, Serine protease } 56 \text { precursor, Uncharacterized protein C11orf24 precursor }\end{array}$ \\
\hline QAIVSS & Ataxin-2-like protein \\
\hline PPTAPP & B-cell CLL/lymphoma 6 member B protein, B-cell CLL/lymphoma 9-like protein \\
\hline SLSPVP & $\begin{array}{l}\text { BCLAF1 and THRAP3 family member 3, Mucin-5AC precursor, Zinc finger and SCAN domain-containing } \\
\text { protein } 22\end{array}$ \\
\hline APQVLP & Cadherin-2 precursor \\
\hline QEVSRL & $\begin{array}{c}\text { Calpain-10, Caseinolytic peptidase B protein homolog precursor, Dehydrogenase/reductase SDR family } \\
\text { member 7C precursor, Kinesin-like protein KIFC3, Leucine-rich repeat-containing protein 69, Nucleobindin-1 } \\
\text { precursor, Transcription factor MafB }\end{array}$ \\
\hline RPPPGP & $\begin{array}{l}\text { Carbohydrate-responsive element-binding protein, Cyclic GMP-AMP synthase, Helicase SRCAP, Homeobox } \\
\text { protein HMX1, Membrane protein FAM174B precursor, Monocarboxylate transporter 3, Potassium/sodium } \\
\text { hyperpolarization-activated cyclic nucleotide-gated channel 2, Proline-rich protein Y-linked, Sprouty-related, } \\
\text { EVH1 domain-containing protein } 3\end{array}$ \\
\hline APGYDP & Carboxypeptidase $\mathrm{N}$ catalytic chain precursor \\
\hline TQPRPP & CCR4-NOT transcription complex subunit 3 \\
\hline $\begin{array}{l}\text { KDLQAI, } \\
\text { DLQAIK }\end{array}$ & Cilia- and flagella-associated protein 44 \\
\hline VLPVMH & Coiled-coil domain-containing protein 77 \\
\hline QLPPTA & Constitutive coactivator of PPAR-gamma-like protein 2 \\
\hline AIVSSP & Cullin-9 \\
\hline CTQPRP & Cyclin-G-associated kinase \\
\hline PPLLPH & Dedicator of cytokinesis protein 9 \\
\hline PLLPHS & Dedicator of cytokinesis protein 9, LIM/homeobox protein Lhx8, Probable palmitoyltransferase ZDHHC11B \\
\hline SLALPA & Dedicator of cytokinesis protein 9, Transmembrane protein 130 precursor \\
\hline APPLLP & DNA methyltransferase 1-associated protein 1, Protein AF-17, Synaptojanin-2, Transcription factor HES-4 \\
\hline PPPGPC & DNA polymerase nu, Protein FAM214B, Tastin \\
\hline NTEPSQ & DNA topoisomerase 2-binding protein 1 \\
\hline IDGRVI & DnaJ homolog subfamily B member 5 \\
\hline
\end{tabular}


Table 3. Cont.

\begin{tabular}{|c|c|}
\hline Peptides & Human Proteins \\
\hline PLCQDP & Dynein heavy chain 14 , axonemal \\
\hline QEVSQA & Dynein heavy chain 3 , axonemal \\
\hline APGYDP & E3 ubiquitin-protein ligase HECTD1 \\
\hline LPPFSL & E3 ubiquitin-protein ligase ZNF598 \\
\hline PYTGAV & Endoplasmic reticulum resident protein 29 precursor \\
\hline PSQLPP & $\begin{array}{l}\text { Fertilization-influencing membrane protein, Mediator of RNA polymerase II transcription subunit 15, } \\
\text { Mitochondrial import inner membrane translocase subunit Tim17-B, Protein KRBA1, Zinc finger and BTB } \\
\text { domain-containing protein } 32\end{array}$ \\
\hline PSLALP & FLYWCH-type zinc finger-containing protein 1 \\
\hline TAPPLL & Forkhead box protein Q1 \\
\hline PPTAPP & Forkhead box protein Q1, Immediate early response gene 2 protein \\
\hline $\begin{array}{l}\text { LQAIKQ, } \\
\text { QAKQE }\end{array}$ & Heterogeneous nuclear ribonucleoprotein C-like 1 \\
\hline DLQAIK & Heterogeneous nuclear ribonucleoprotein C-like 1, Heterogeneous nuclear ribonucleoproteins C1/C2 \\
\hline DGRVIG & Histone acetyltransferase KAT2A, Histone acetyltransferase KAT2B \\
\hline LYPSLA & Host cell factor 2 \\
\hline YPSLAL & Integrin beta- 5 precursor \\
\hline MKDLQA & Islet cell autoantigen 1 \\
\hline GAVSSP & Kallikrein-9 precursor \\
\hline PRPPPG & $\begin{array}{l}\text { Carbohydrate-responsive element-binding protein, Cyclic GMP-AMP synthase, Homeobox protein HMX1, } \\
\text { Kelch domain-containing protein 7A, Microtubule organization protein AKNA, Proline-rich protein 33, RING } \\
\text { finger protein 225, Splicing factor 3B subunit 4, Tau-tubulin kinase 2, Trinucleotide repeat-containing gene 6B } \\
\text { protein, Proline-rich protein, Y-linked }\end{array}$ \\
\hline NLDHIL & Kinocilin \\
\hline AIKQEV & La-related protein 1B \\
\hline DPQIQA & Mediator of RNA polymerase II transcription subunit 17 \\
\hline EPSQLP & Membrane primary amine oxidase \\
\hline LSPVPT & Mucin-5AC precursor \\
\hline TQPRPP & N-acetyl-beta-glucosaminyl-glycoprotein 4-beta-N-acetylgalactosaminyltransferase 1 \\
\hline TGAVSS & Neurofascin precursor \\
\hline LLYPSL & Olfactory receptor $6 \mathrm{P} 1$ \\
\hline PLLYPS & Olfactory receptor $6 \mathrm{P} 1$, Trace amine-associated receptor 5 \\
\hline ALPAPH & PR domain zinc finger protein 12 \\
\hline PPGPCP & Proline-rich protein 13 \\
\hline AIKQEV & Protein C-ets-1 \\
\hline SQLPPT & Protein KRBA1 \\
\hline PPNHRP & Protein piccolo \\
\hline PPTAPP & Protein sidekick-2 precursor, Stanniocalcin-2 precursor \\
\hline PFSLSP & Protein-glucosylgalactosylhydroxylysine glucosidase \\
\hline LVDAPG & Receptor-type tyrosine-protein kinase FLT3 precursor \\
\hline APQVLP & Regulating synaptic membrane exocytosis protein 1 , Serine/threonine-protein kinase WNK1 \\
\hline GAVSSP & RELT-like protein 1 precursor \\
\hline
\end{tabular}


Table 3. Cont

\begin{tabular}{cc}
\hline Peptides & Human Proteins \\
\hline LPPTAP & SH3 and multiple ankyrin repeat domains protein 1 \\
\hline TGAVSS & Sorbin and SH3 domain-containing protein 1 \\
\hline TQPRPP & Spectrin beta chain, non-erythrocytic 2 \\
\hline KFQHDV & Testis-expressed protein 38 \\
\hline LATCPE & Thrombospondin-1 precursor \\
\hline KDLQAI & WW domain-binding protein 4 \\
\hline ILEPSI & Zinc finger homeobox proteins 3 and 4 \\
\hline CPLCQD & Zinc finger homeobox protein 4 \\
\hline LEPSIP & Zinc finger protein 57 homolog, Zinc finger proteins $69,101,124,136,334,439,440,442,563,669,700,709,763$, \\
VNFTQE & $823,844,878$ \\
\hline DVNFTQ & Zinc finger protein 136 \\
\hline
\end{tabular}

Reasons of space hamper a protein-by-protein discussion and here we focus on some potentially biologically relevant target proteins (identified by their UniProt name; peptides shared with HTLV-1 are given in parentheses) and the related pathologies that could arise in case of cross-reactivity. Examples among the many are:

- A-kinase anchor protein 1, mitochondrial precursor (PSLALP) has a pivotal role in mitochondrial physiology, and its degradation leads to an increase in reactive oxygen species production, mitochondrial dysfunction, and ultimately cell death [16].

- A-kinase anchor protein 7 isoform gamma (HLTLPF) modulates L-type Ca2+ channels [17]. Alterations of L-type Ca2+ channels may affect cardiac contraction [18], associate with diabetes [19] and can cause autism [20] and relate to Alzheimer's disease, Parkinson's disease, Huntington's disease, neuropsychiatric diseases, and other CNS disorders [21].

- Ataxin-2-like protein (QAIVSS) is involved in spinocerebellar ataxia type 2 [22], cutaneous T-cell lymphomas [23], is directly relevant to allergic disease [24], and its absence triggers mid-gestational embryonic lethality, affecting female animals more strongly [25].

- B-cell CLL/lymphoma 6 member B protein and B-cell CLL/lymphoma 9-like protein, both of which share the peptide PPTAPP with HTLV-1. When altered, these two proteins relate to tumorigenesis [26].

- Cadherin-2 (APQVLP) may be associated with reduction in bone mineral density or vertebral fracture prevalence in survivors of childhood acute lymphoblastic leukemia [27].

- Constitutive coactivator of PPAR-gamma-like protein 2 (QLPPTA) deletion is associated with autism [28].

- Dedicator of cytokinesis protein 9 (PPLLPH, PLLPHS, SLALPA) contributes to both risk and increased illness severity in bipolar disorder [29].

- DNA methyltransferase 1-associated protein 1 (APPLLP) is an essential regulator of activity and function of Ataxia Telangiectasia Mutated (ATM) kinase [30]. Alterations of the function and activity of ATM cause severe disability, poor coordination and telangiectasia, i.e., small dilated blood vessels [31].

- $\quad$ DNA polymerase nu (PPPGPC) plays a role in translesion DNA synthesis during interstrand cross-link repair in human cells [32].

- $\quad$ E3 ubiquitin-protein ligase HECTD1 (APGYDP) is an important factor in promoting base excision repair (BER), which is the major cellular DNA repair pathway that recognizes and excises damaged DNA bases to help maintain genome stability [33].

- Fertilization-influencing membrane protein (PSQLPP) plays a role in sperm-oocyte fusion during fertilization [34]. 
- $\quad$ FLYWCH-type zinc finger-containing protein 1 (PSLALP) has a possible tumor suppressive role in preventing colorectal cancer metastasis [35].

- Heterogeneous nuclear ribonucleoprotein C-like 1 (DLQAIK, LQAIKQ, QAKQE), alterations of which are found in sporadic and suspected Lynch syndrome endometrial cancer [36].

- Histone acetyltransferases KAT2A and KAT2B (DGRVIG), when altered, are associated with cardiovascular pathology [37].

- Islet cell autoantigen 1 (MKDLQA) Islet autoantibodies are typically associated with type 1 diabetes, but have been found in patients diagnosed with type 2 diabetes in whom they are associated with lower adiposity [38].

- La-related protein 1B (AIKQEV) is dysregulated in hepatocellular carcinoma [39].

- Mitochondrial dynamics protein MID49 (QPRPPP) is related to myopathies [40].

- Mucin-5AC precursor (SLSPVP, LSPVPT) is a major macromolecular component that determines the rheological properties of mucus; otherwise abnormal not-flowing mucus results in defective lung protection and leads to infection and inflammation [41].

- Neurofascin precursor (TGAVSS), which is a cell adhesion, ankyrin-binding protein, may be involved in neurite extension, axonal guidance, synaptogenesis, myelination, and neuron-glial cell interactions. Anti-neurofascin antibodies relate to optic, trigeminal, and facial neuropathy [42].

- Palmitoyltransferase ZDHHC1 (LALPAP) is involved in innate viral immune response [43].

- Protein piccolo (PPNHRP) is required for the development and function of neuronal networks formed between the brainstem and cerebellum. Alterations of protein piccolo may result in impaired motor coordination, cerebellar network dysfunction and pontocerebellar hypoplasia [44].

- $\quad$ Serine/threonine-protein kinase WNK1 (APQVLP) can cause hereditary sensory and autonomic neuropathy [45].

- Suppressor of tumorigenicity 7 protein (SLILPP) deficiency promotes laryngeal squamous cell carcinoma [46].

- Finally, to conclude this survey of pathologies that may be associated with HTLV-1 infection following cross-reactivity and autoantibody generation, we highlight the HTLV-1 epitope-derived VNFTQE peptide that is present in seventeen zinc finger proteins (ZFP) (numbered in Table 3 as: 57 homolog, 69, 101, 124, 136, 334, 439, $440,442,563,669,700,709,763,823,844$, and 878). Zinc finger proteins comprise transcription factor families that are known for their ability to bind $\mathrm{Zn} 2+$ and are associated with numerous disorders. In the present context, the following are noteworthy: ZFP823 family, when mutated or dysregulated, is involved in acute leukemias [47]. Altered/dysregulated ZFPs may also associate with neurodevelopmental disorders such as intellectual disability, autistic features, psychiatric problems, and motor dysfunction [48]. Moreover, zinc finger proteins are implicated in the development and progression of several types of cancer [49]. Simply put, antibodies against the epitopederived peptide VNFTQE alone might be sufficient to determine the wide range of pathologies that, in more or less severe forms, afflict HTLV-1-infected patients.

\section{Discussion}

Vaccines are a crucial tool for fighting viral infections and their profile of efficacy and safety is of paramount importance. Minimizing the risk of collateral autoimmune cross-reactivity might be advantageous for further optimizing the efficacy-safety tradeoff, as recently shown by the SARS-CoV-2 global vaccination campaign [50,51].

Hence, in order to design a safe and effective HTLV-1 vaccine, we applied the scientific rationale according to which vaccines based on peptides unique to the infectious pathogens and absent in the human host might avoid cross-reactivity phenomena and offer high potential for immunogenicity and self-adjuvanticity $[52,53]$. We found a peptide platform consisting of 15 viral sequences (overall length: $104 \mathrm{aa}$ ) that are unique to the 
HTLV-1 polyprotein when compared to the Homo sapiens proteome. These sequences show an immunological potential by being embedded in epitopes that were experimentally validated in the human host, as shown in Table 2. Of note, the vast majority of such epitopes are characterized by B cell immunoreactivity and only to a minor degree by cell-mediated immune response, thus suggesting mainly humoral protective immunity. Humoral immunity is not restricted to extracellular antigens, as it can also neutralize viruses within infected cells and bind intracytoplasmic antigens [54,55]. Antibodies induced by our peptide platform might therefore be able to interact with viral proteins within HTLV-1-infected cells [56].

\subsection{Translational Potential and Advantages for $m R N A$ Vaccines}

Messenger ribonucleic acid (mRNA) vaccines are the results of decades of studies on different mRNA intracellular delivery technologies and have come under the spotlight as one of the main tools of the global vaccination campaign against the severe acute respiratory syndrome coronavirus 2 (SARS-CoV-2) [57]. Delivery is crucial to this formulation technology because of the inherent instability of mRNA and lipid nanoparticle carriers have been adopted in order to strike the best compromise between stability and effective intracellular release [58]. Nevertheless, the real-world logistics of the mRNA vaccines during the pandemic has proven to be challenging, requiring, for instance, strict cold chain integrity [59], and product integrity issues have appeared to affect largescale production [60]. Of relevance, the larger size of mRNA as compared, for example, to small interfering RNA or other smaller molecules complicates efficient encapsulation in the nanoparticles $[57,61]$. Moreover, mRNA size inversely correlates with translational rate $[62,63]$. The epitope platform we presented here consists of 15 epitopes for a total of 104 residues that can be extended by spacer links to 400 aa to optimize translation [64]. Such length would correspond to a third of the size of the SARS-CoV-2 spike protein encoded by the only currently available mRNA vaccines and, by comparison, might lead to more efficient encapsulation and, after delivery, translation of the mRNA, eventually resulting in optimal translation, antigen production, and immunization.

\subsection{Translational Potential and Advantages for Peptide-Based Vaccines}

The epitope platform presented above can also be adopted in non-genetic peptidebased vaccine formulations, where the peptides are directly administered, possibly conjugated to a carrier [65]. Such formulations are easy to mass-produce, are chemically stable, and do not pose any risk of infectious or oncogenic potential. Our specific uniquely viral epitope platform additionally minimizes the risk of autoimmunity with potential high self-adjuvanticity [53]. Crucially, we previously identified, with the same approach adopted in the present work, potential epitopes of SARS-CoV-2 [52] and a number of them were subsequently experimentally confirmed to be safe and effective in eliciting immunity against the virus with a peptide-based vaccine $[66,67]$.

\section{Conclusions}

We presented here an epitope platform for effective HTLV-1 vaccination that minimizes the risks intrinsic to whole viral antigens, thus potentially reducing post-vaccination adverse events, cross-reactivity with human antigens and possible autoimmune pathologies [68].

The short epitopes we identified are optimally suited for mRNA and nanoparticle vaccine technology, offering remarkable advantage in terms of production quality and stability of the final products, thus easing the currently challenging logistic aspects of storage and transportation. Moreover, the same epitope platform is a flexible resource that can also be used in peptide-based vaccines at lower cost, facilitating production and diffusion, for instance in developing countries. 
In sum, we presented an epitope set that offers remarkable real-world logistic advantages for a large-scale safe and effective prophylactic vaccination campaign against HTLV-1 that might be of cogent importance considering that no specific therapy exists.

Author Contributions: G.L., H.R.J., P.L. and A.S. conceived the study. G.L., H.R.J. and A.S. searched the literature. L.D.B. contributed to writing-review and editing. Data analysis was carried out by G.L., H.R.J. and A.S., G.L., H.R.J. and A.S. contributed to initial drafting of the manuscript. All of the authors contributed to interpretation of data and critical revision of the report. All authors have read and agreed to the published version of the manuscript.

Funding: This research received no external funding.

Institutional Review Board Statement: Not applicable.

Informed Consent Statement: Not applicable.

Data Availability Statement: All data are either contained in the article or available at the links provided in the article.

Acknowledgments: G.L. acknowledges support from the Universitätsmedezin Greifswald in form of a "Gerhard Domagk" research grant. The funding body had no role in the design of the study and collection, analysis, and interpretation of data and in writing the manuscript.

Conflicts of Interest: The authors declare no conflict of interest.

\section{References}

1. Schierhout, G.; McGregor, S.; Gessain, A.; Einsiedel, L.; Martinello, M.; Kaldor, J. Association between HTLV-1 infection and adverse health outcomes: A systematic review and meta-analysis of epidemiological studies. Lancet Infect. Dis. 2020, 20, 133-143. [CrossRef]

2. Khan, M.Y.; Khan, I.N.; Farman, M.; Al Karim, S.; Qadri, I.; Kamal, M.A.; Al Ghamdi, K.; Harakeh, S. HTLV-1 Associated Neurological Disorders. Curr. Top. Med. Chem. 2017, 17, 1320-1330. [CrossRef] [PubMed]

3. Romanelli, L.C.F.; Caramelli, P.; Martins, M.L.; Gonçalves, D.U.; Proietti, F.A.; Ribas, J.G.; Araújo, M.G.; Carneiro-Proietti, A.B.D.F. Incidence of Human T Cell Lymphotropic Virus Type 1-Associated Myelopathy/Tropical Spastic Paraparesis in a Long-Term Prospective Cohort Study of Initially Asymptomatic Individuals in Brazil. AIDS Res. Hum. Retrovir. 2013, 29, 1199-1202. [CrossRef] [PubMed]

4. Quaresma, J.A.S.; Yoshikawa, G.T.; Koyama, R.V.L.; Dias, G.A.S.; Fujihara, S.; Fuzii, H.T. HTLV-1, Immune Response and Autoimmunity. Viruses 2015, 8, 5. [CrossRef]

5. Levin, M.; Lee, S.M.; Kalume, F.; Morcos, Y.; Curtis Dohan, F., Jr.; Hasty, K.A.; Callaway, J.C.; Zunt, J.; Desiderio, D.M.; Stuart, J.M. Autoimmunity due to molecular mimicry as a cause of neurological disease. Nat. Med. 2002, 8, 509-513. [CrossRef]

6. Kabiri, M.; Sankian, M.; Hosseinpour, M.; Tafaghodi, M. The novel immunogenic chimeric peptide vaccine to elicit potent cellular and mucosal immune responses against HTLV-1. Int. J. Pharm. 2018, 549, 404-414. [CrossRef]

7. Kabiri, M.; Sankian, M.; Sadri, K.; Tafaghodi, M. Robust mucosal and systemic responses against HTLV-1 by delivery of multi-epitope vaccine in PLGA nanoparticles. Eur. J. Pharm. Biopharm. 2018, 133, 321-330. [CrossRef]

8. Kannagi, M.; Hasegawa, A.; Nagano, Y.; Iino, T.; Okamura, J.; Suehiro, Y. Maintenance of long remission in adult T-cell leukemia by Tax-targeted vaccine: A hope for disease-preventive therapy. Cancer Sci. 2019, 110, 849-857. [CrossRef]

9. Kanduc, D. "Self-Nonself" Peptides in the Design of Vaccines. Curr. Pharm. Des. 2009, 15, 3283-3289. [CrossRef] [PubMed]

10. Kanduc, D. Peptide cross-reactivity the original sin of vaccines. Front. Biosci. 2012, S4, 1393-1401. [CrossRef]

11. The UniProt Consortium. UniProt: A worldwide hub of protein knowledge. Nucleic Acids Res. 2019, 47, D506-D515. [CrossRef]

12. Chen, C.; Li, Z.; Huang, H.; Suzek, B.E.; Wu, C.H.; UniProt Consortium. A fast PeptideMatch service for UniProt knowledgebase. Bioinformatics 2013, 29, 2808-2809. [CrossRef]

13. Vita, R.; Mahajan, S.; Overton, J.A.; Dhanda, S.K.; Martini, S.; Cantrell, J.R. The immune epitope database (IEDB): 2018 update. Nucleic Acids Res. 2019, 47, D339-D343. [CrossRef]

14. Andreatta, M.; Nielsen, M. Gapped sequence alignment using artificial neural networks: Application to the MHC class I system. Bioinformatics 2016, 32, 511-517. [CrossRef]

15. Alam, S.; Hasan, K.; Bin Manjur, O.H.; Khan, A.; Sharmin, Z.; Pavel, M.A.; Hossain, F. Predicting and Designing Epitope Ensemble Vaccines against HTLV-1. J. Integr. Bioinform. 2020, 16. [CrossRef]

16. Czachor, A.; Failla, A.; Lockey, R.; Kolliputi, N. Pivotal role of AKAP121 in mitochondrial physiology. Am. J. Physiol. Physiol. 2016, 310, C625-C628. [CrossRef] [PubMed]

17. Fraser, I.; Scott, J.D. Modulation of Ion Channels: A “Current” View of AKAPs. Neuron 1999, 23, 423-426. [CrossRef]

18. Lu, F.; Pu, W.T. The architecture and function of cardiac dyads. Biophys. Rev. 2020, 12, 1007-1017. [CrossRef]

19. Nieves-Cintrón, M.; Tamez, V.A.; Le, T.; Baudel, M.M.-A.; Navedo, M.F. Cellular and molecular effects of hyperglycemia on ion channels in vascular smooth muscle. Cell. Mol. Life Sci. 2021, 78, 31-61. [CrossRef] [PubMed] 
20. Marcantoni, A.; Calorio, C.; Hidisoglu, E.; Chiantia, G.; Carbone, E. Cav1.2 channelopathies causing autism: New hallmarks on Timothy syndrome. Pflügers Arch. Eur. J. Physiol. 2020, 472, 1-15. [CrossRef] [PubMed]

21. Hopp, S.C. Targeting microglia L-type voltage-dependent calcium channels for the treatment of central nervous system disorders. J. Neurosci. Res. 2021, 99, 141-162. [CrossRef] [PubMed]

22. Kaehler, C.; Isensee, J.; Nonhoff, U.; Terrey, M.; Hucho, T.; Lehrach, H.; Krobitsch, S. Ataxin-2-Like Is a Regulator of Stress Granules and Processing Bodies. PLoS ONE 2012, 7, e50134. [CrossRef] [PubMed]

23. Panagopoulos, I.; Gorunova, L.; Spetalen, S.; Bassarova, A.; Beiske, K.; Micci, F.; Heim, S. Fusion of the genes ataxin 2 like, ATXN2L, and Janus kinase 2, JAK2, in cutaneous CD4 positive T-cell lymphoma. Oncotarget 2017, 8, 103775-103784. [CrossRef] [PubMed]

24. Ferreira, M.A.; Vonk, J.M.; Baurecht, H.; Marenholz, I.; Tian, C.; Hoffman, J.D.; Helmer, Q.; Tillander, A.; Ullemar, V.; Lu, Y.; et al. Eleven loci with new reproducible genetic associations with allergic disease risk. J. Allergy Clin. Immunol. 2019, 143, 691-699. [CrossRef] [PubMed]

25. Key, J.; Harter, P.N.; Sen, N.-E.; Gradhand, E.; Auburger, G.; Gispert, S. Mid-Gestation lethality of Atxn2l-Ablated Mice. Int. J. Mol. Sci. 2020, 21, 5124. [CrossRef]

26. Wang, J.; Dong, L.; Xu, L.; Chu, E.S.; Chen, Y.; Shen, J.; Li, X.; Wong, C.C.; Sung, J.J.Y.; Yu, J. B cell CLL/lymphoma 6 member B inhibits hepatocellular carcinoma metastases in vitro and in mice. Cancer Lett. 2014, 355, 192-200. [CrossRef]

27. Aaron, M.; Nadeau, G.; Ouimet-Grennan, E.; Drouin, S.; Bertout, L.; Beaulieu, P.; St-Onge, P.; Shalmiev, A.; Veilleux, L.N.; Rauch, F; et al. Identification of a single-nucleotide polymorphism within CDH2 gene associated with bone morbidity in childhood acute lymphoblastic leukemia survivors. Pharmacogenomics 2019, 20, 409-420. [CrossRef]

28. De Wolf, V.; Crepel, A.; Schuit, F.; van Lommel, L.; Ceulemans, B.; Steyaert, J.; Seuntjens, E.; Peeters, H.; Devriendt, K. A complex Xp11.22 deletion in a patient with syndromic autism: Exploration ofFAM120Cas a positional candidate gene for autism. Am. J. Med. Genet. Part A 2014, 164, 3035-3041. [CrossRef]

29. Detera-Wadleigh, S.D.; Liu, C.; Maheshwari, M.; Cardona, I.; Corona, W.; Akula, N.; Steele, C.; Badner, J.A.; Kundu, M.; Kassem, L.; et al. Sequence variation in DOCK9 and heterogeneity in bipolar disorder. Psychiatr. Genet. 2007, 17, $274-286$. [CrossRef]

30. Penicud, K.; Behrens, A. DMAP1 is an essential regulator of ATM activity and function. Oncogene 2014, 33, 525-531. [CrossRef] [PubMed]

31. De Oliveira, B.S.P.; Putti, S.; Naro, F.; Pellegrini, M. Bone Marrow Transplantation as Therapy for Ataxia-Telangiectasia: A Systematic Review. Cancers 2020, 12, 3207. [CrossRef]

32. Zietlow, L.; Smith, L.A.; Bessho, M.; Bessho, T. Evidence for the Involvement of Human DNA Polymerase N in the Repair of DNA Interstrand Cross-Links. Biochemistry 2009, 48, 11817-11824. [CrossRef] [PubMed]

33. Bennett, L.; Madders, E.C.E.T.; Parsons, J.L. HECTD1 promotes base excision repair in nucleosomes through chromatin remodelling. Nucleic Acids Res. 2019, 48, 1301-1313. [CrossRef] [PubMed]

34. Fujihara, Y.; Lu, Y.; Noda, T.; Oji, A.; Larasati, T.; Kojima-Kita, K.; Yu, Z.; Matzuk, R.M.; Matzuk, M.M.; Ikawa, M. Spermatozoa lacking Fertilization Influencing Membrane Protein (FIMP) fail to fuse with oocytes in mice. Proc. Natl. Acad. Sci. USA 2020, 117, 9393-9400. [CrossRef]

35. Muhammad, B.A.; Almozyan, S.; Babaei-Jadidi, R.; Onyido, E.; Saadeddin, A.; Kashfi, S.H.; Spencer-Dene, B.; Ilyas, M.; Lourdusamy, A.; Behrens, A.; et al. FLYWCH1, a Novel Suppressor of Nuclear $\beta$-Catenin, Regulates Migration and Morphology in Colorectal Cancer. Mol. Cancer Res. 2018, 16, 1977-1990. [CrossRef]

36. Gao, Y.; Zhang, X.; Wang, T.; Zhang, Y.; Wang, Q.; Hu, Y. HNRNPCL1, PRAMEF1, CFAP74, and DFFB: Common Potential Biomarkers for Sporadic and Suspected Lynch Syndrome Endometrial Cancer. Cancer Manag. Res. 2020, 12, 11231-11241. [CrossRef] [PubMed]

37. Han, Y.; Tanios, F.; Reeps, C.; Zhang, J.; Schwamborn, K.; Eckstein, H.-H.; Zernecke, A.; Pelisek, J. Histone acetylation and histone acetyltransferases show significant alterations in human abdominal aortic aneurysm. Clin. Epigenetics 2016, 8, 1-13. [CrossRef] [PubMed]

38. Pilla, S.J.; Balasubramanyam, A.; Knowler, W.C.; Lazo, M.; Nathan, D.M.; Pi-Sunyer, X.; Clark, J.M.; Maruthur, N.M.; The Look AHEAD Research Group. Islet autoantibody positivity in overweight and obese adults with type 2 diabetes. Autoimmunity 2018, 51, 408-416. [CrossRef]

39. Wang, M.; Huang, S.; Chen, Z.; Han, Z.; Li, K.; Chen, C.; Wu, G.; Zhao, Y. Development and validation of an RNA binding protein-associated prognostic model for hepatocellular carcinoma. BMC Cancer 2020, 20, 1-14. [CrossRef]

40. Bartsakoulia, M.; Pyle, A.; Troncoso-Chandía, D.; Vial-Brizzi, J.; Paz-Fiblas, M.V.; Duff, J.; Griffin, H.; Boczonadi, V.; Lochmüller, H.; Kleinle, S.; et al. A novel mechanism causing imbalance of mitochondrial fusion and fission in human myopathies. Hum. Mol. Genet. 2018, 27, 1186-1195. [CrossRef]

41. Ridley, C.; Thornton, D.J. Mucins: The frontline defence of the lung. Biochem. Soc. Trans. 2018, 46, 1099-1106. [CrossRef] [PubMed]

42. Ogata, H.; Zhang, X.; Inamizu, S.; Yamashita, K.; Yamasaki, R.; Matsushita, T.; Isobe, N.; Hiwatashi, A.; Tobimatsu, S.; Kira, J. Optic, trigeminal, and facial neuropathy related to anti-neurofascin 155 antibody. Ann. Clin. Transl. Neurol. 2020, 7, $2297-2309$. [CrossRef]

43. Sowers, M.L.; Tang, H.; Tian, B.; Goldblum, R.; Midoro-Horiuti, T.; Zhang, K. Bisphenol A Activates an Innate Viral Immune Response Pathway. J. Proteome Res. 2019, 19, 644-654. [CrossRef] [PubMed] 
44. Falck, J.; Bruns, C.; Hoffmann-Conaway, S.; Straub, I.; Plautz, E.J.; Orlando, M.; Munawar, H.; Rivalan, M.; Winter, Y.; Izsvák, Z.; et al. Loss of Piccolo Function in Rats Induces Cerebellar Network Dysfunction and Pontocerebellar Hypoplasia Type 3-like Phenotypes. J. Neurosci. 2020, 40, 2943-2959. [CrossRef] [PubMed]

45. Lafrenière, R.G.; Macdonald, M.L.E.; Dubé, M.-P.; Macfarlane, J.; O’Driscoll, M.; Brais, B.; Meilleur, S.; Brinkman, R.R.; Dadivas, O.; Pape, T.; et al. Identification of a Novel Gene (HSN2) Causing Hereditary Sensory and Autonomic Neuropathy Type II through the Study of Canadian Genetic Isolates. Expand. Spectr. BAF Relat. Disord. De Novo Var. SMARCC2 Cause Syndr. Intellect. Disabil. Dev. Delay 2004, 74, 1064-1073. [CrossRef]

46. Qin, H.; Xu, J.; Gong, L.; Jiang, B.; Zhao, W. The long noncoding RNA ST7-AS1 promotes laryngeal squamous cell carcinoma by stabilizing CARM1. Biochem. Biophys. Res. Commun. 2019, 512, 34-40. [CrossRef]

47. Schuschel, K.; Helwig, M.; Hüttelmaier, S.; Heckl, D.; Klusmann, J.-H.; Hoell, J.I. RNA-Binding Proteins in Acute Leukemias. Int. J. Mol. Sci. 2020, 21, 3409. [CrossRef]

48. Al-Naama, N.; Mackeh, R.; Kino, T. C2H2-Type Zinc Finger Proteins in Brain Development, Neurodevelopmental, and Other Neuropsychiatric Disorders: Systematic Literature-Based Analysis. Front. Neurol. 2020, 11, 32. [CrossRef] [PubMed]

49. Ye, Q.; Liu, J.; Xie, K. Zinc finger proteins and regulation of the hallmarks of cancer. Histol. Histopathol. $2019,34,18121$.

50. Greinacher, A.; Thiele, T.; Warkentin, T.E.; Weisser, K.; Kyrle, P.A.; Eichinger, S. Thrombotic Thrombocytopenia after ChAdOx1 nCov-19 Vaccination. N. Engl. J. Med. 2021, 384, 2092-2101. [CrossRef]

51. Greinacher, A.; Selleng, K.; Mayerle, J. Anti-SARS-CoV-2 Spike Protein and Anti-Platelet Factor 4 Antibody Responses Induced by COVID-19 Disease and ChAdOx1 nCov-19 vaccination. Res. Sq. 2021, preprint. [CrossRef]

52. Lucchese, G. Epitopes for a 2019-nCoV vaccine. Cell. Mol. Immunol. 2020, 17, 539-540. [CrossRef]

53. Patel, A.; Dong, J.C.; Trost, B.; Richardson, J.S.; Tohme, S.; Babiuk, S.; Kusalik, A.; Kung, S.K.P.; Kobinger, G.P. Pentamers Not Found in the Universal Proteome Can Enhance Antigen Specific Immune Responses and Adjuvant Vaccines. PLoS ONE 2012, 7, e43802. [CrossRef]

54. Mallery, D.L.; McEwan, W.; Bidgood, S.; Towers, G.; Johnson, C.M.; James, L.C. Antibodies mediate intracellular immunity through tripartite motif-containing 21 (TRIM21). Proc. Natl. Acad. Sci. USA 2010, 107, 19985-19990. [CrossRef] [PubMed]

55. Greenlee, J.E.; Clawson, S.A.; Hill, K.E.; Wood, B.; Clardy, S.L.; Tsunoda, I.; Carlson, N.G. Anti-Yo Antibody Uptake and Interaction with Its Intracellular Target Antigen Causes Purkinje Cell Death in Rat Cerebellar Slice Cultures: A Possible Mechanism for Paraneoplastic Cerebellar Degeneration in Humans with Gynecological or Breast Cancers. PLoS ONE 2015, 10, e0123446. [CrossRef] [PubMed]

56. Enose-Akahata, Y.; Abrams, A.; Massoud, R.; Bialuk, I.; Johnson, K.R.; Green, P.L.; Maloney, E.M.; Jacobson, S. Humoral immune response to HTLV-1 basic leucine zipper factor (HBZ) in HTLV-1-infected individuals. Retrovirology 2013, 10, 19. [CrossRef]

57. Zeng, C.; Zhang, C.; Walker, P.G.; Dong, Y. Formulation and Delivery Technologies for mRNA Vaccines. In Current Topics in Microbiology and Immunology; Springer Science and Business Media LLC: Berlin/Heidelberg, Germany, 2020.

58. Igyártó, B.Z.; Jacobsen, S.; Ndeupen, S. Future considerations for the mRNA-lipid nanoparticle vaccine platform. Curr. Opin. Virol. 2021, 48, 65-72. [CrossRef] [PubMed]

59. Crommelin, D.J.; Anchordoquy, T.J.; Volkin, D.B.; Jiskoot, W.; Mastrobattista, E. Addressing the Cold Reality of mRNA Vaccine Stability. J. Pharm. Sci. 2021, 110, 997-1001. [CrossRef]

60. Tinari, S. The EMA covid-19 data leak, and what it tells us about mRNA instability. BMJ 2021, 372, n627. [CrossRef]

61. Brader, M.L.; Williams, S.J.; Banks, J.M.; Hui, W.H.; Zhou, Z.H.; Jin, L. Encapsulation state of messenger RNA inside lipid nanoparticles. Biophys. J. 2021, 25, S0006-3495(21)00241-1. [CrossRef]

62. Valleriani, A.; Zhang, G.; Nagar, A.; Ignatova, Z.; Lipowsky, R. Length-dependent translation of messenger RNA by ribosomes. Phys. Rev. E 2011, 83, 042903. [CrossRef] [PubMed]

63. Zhang, Y. Comment on "Length-dependent translation of messenger RNA by ribosomes". Phys. Rev. E 2012, 85, 023901. [CrossRef]

64. Liao, H.X.; Spremulli, L.L. Effects of length and mRNA secondary structure on the interaction of bovine mitochondrial ribo-somes with messenger RNA. J. Biol. Chem. 1990, 265, 11761-11765. [CrossRef]

65. Malonis, R.J.; Lai, J.R.; Vergnolle, O. Peptide-Based Vaccines: Current Progress and Future Challenges. Chem. Rev. 2020, 120, 3210-3229. [CrossRef] [PubMed]

66. Ryzhikov, A.B.; Ryzhikov E.A.; Bogryantseva, M.P.; Usova, S.V.; Danilenko, E.D.; Nechaeva, E.A.; Pyankov, O.V.; Pyankova, O.G.; Gudymo, A.S. A single blind, placebo-controlled randomized study of the safety, reactogenicity and immunogenicity of the "EpiVacCorona" Vaccine for the prevention of COVID-19, in volunteers aged 18-60 years (phase I-II). Russ. J. Infect. Immun. 2021, 11, 283-296. [CrossRef]

67. Ryzhikov, A.B. Peptide Immunogens and Vaccine Composition against Coronavirus Infection COVID-19 Using Peptide Immunogens. Russian Federration. Patent No. 2738081, 7 December 2020.

68. Lucchese, G.; Stufano, A.; Kanduc, D. Searching for an effective, safe and universal anti-HIV vaccine: Finding the answer in just one short peptide. Self Nonself 2011, 2, 49-54. [CrossRef] 